\title{
Plot vs Emplotment - Testing the narrative concepts of aesthetics and authenticity in the documentary short Far Away Land
}

\author{
Deirdre O'Toole \\ IADT, Ireland \\ Queen's University Belfast, Northern Ireland
}

\begin{abstract}
This paper recounts the research and production of Far Away Land, a short documentary that uses recreations to illustrate a woman's memory of drowning. The images used to illustrate the narrator's experience will be interrogated to establish how they might enhance or take from the original story. The idea of plot vs emplotment will be explored in this paper to explore how the aesthetics and visualisations of recreations reflect, compliment and contrast with voice-over narrative. This paper also investigates the relationship between linking visual imagery to the narrator in the absence of an on-camera interview. Placing this short film in the lineage of documentaries that use recreation the efficacy of this style will be discussed in terms of delivering an authentic and aesthetic documentary film.
\end{abstract}

Keywords: Cinematography, Film, Documentary, Storytelling, Practice as Research

\section{Introduction}

Far Away Land is a documentary about a woman who recounts how she was swimming off Nantucket Island at a beach unfamiliar to her, when she became caught by the tides and felt unable to get back to the shore. She thought her life was over and came to realise how fragile she was when confronted with the strength of the Atlantic Ocean. This film is part of a larger $\mathrm{PhD}$ project which is concerned with aesthetically and authentically documenting stories of drowning. Far Away Land is structured around a voice-over interview with Catherine Redmond where she recalls this traumatic event and this testimony becomes the 'plot' or story of the film. The 'emplotment' or visualisation of her story is in two parts: the first section is an observational sequence of Catherine on a recent diving expedition, the rest of the film is a reenactment of the event itself which occurred over thirty years previously.

The concept of plot vs emplotment has its origins in narrative theory which delineates between the plot, which is the story being told, and emplotment which is how it is visualised (Good, 1994, Reissman, 2003). Here the word 'plot' is used to describe the narrative spoken by the interviewees and 'emplotment' is used to describe the visual storytelling that accompanies the plot. This is very different from the formalist Russian filmmakers who defined the fabula (the plot) and syuzhet (the story) (Bordwell, 1985). The Formalists influenced the Constructivist film movement, popular in Russia at the time (Redfern, 2005) and adopted by many influential filmmakers including Dziga Vertov. Some of Vertov's ideas of authenticity and aesthetics were influential in the production of this documentary and will be discussed later in this paper. Before this the concepts of aesthetics and authenticity will be discussed. Then there will be a summation of working with Catherine Redmond as a storyteller and the processes involved in translating her narrative to the screen. Following the exploration of Vertov's work details of the screening of this documentary will be outlined.

John Grierson is considered to have provided one of the most durable definitions of documentary, which he considered to be the "artistic representation of reality" (Aufderheide, 2007,3). Grierson developed his definition beyond that of a medium through which to replicate reality, saying, "documentary is simply that in its use of the living article, there is also an opportunity to perform creative work" (Grierson, 1946, 80). With this definition, he highlights the importance of creativity when translating a nonfiction story to the screen. However, the translation of a factual story to the screen is inherently conflicted as the camera cannot perfectly capture what is in front of the lens without manipulation of some sort by the filmmaker; either simply by their choice of composition, in the editing process or, more intricately, in the choice of visual representation, reenactments and the visual metaphors used in order to have a desired impact for the viewer (Nichols, 1991, Hill and Church Gibson, 1998). This conflict can be seen as a clash between authenticity and aesthetics or of plot vs emplotment. Hill and Church Gibson (1998) claim that the first accounts of "inauthentic" films (Von Stroheim's Greed 1925, Welles's The Magnificent Ambersons 1942) arose due to directorial control. This was considered to occur when the control of a film's edit, storyline or production were removed from the director and assumed instead by a studio, producer or sometimes even film distributor or projectionist. When this happened the films were then considered inauthentic to their original construction (14). The explorations of authenticity in this paper go beyond the idea of the auteur as a cohesive and detached presence. To this aim an analysis of aesthetics and authenticity in the documentary tradition is provided as these underpin the concepts explored practically in the decisions made in the production of the documentary short Far Away Land (2017).

\section{Aesthetics}

The term 'aesthetic' comes from the Greek term for sensory perception. It later emerged as a philosophical concept in the Eighteenth Century when it became synonymous with the concept of taste as a reaction to 
rationalists who sought to bring to art and literature the mathematical rigour brought to science by Descartes. Philosophers such as Kant postulated that judgements about an object or document on first glance are rooted more in the viewers own sensory experience than in the application of concepts and theories. This is called The Immediacy Thesis, which contends that the immediacy of sensation will be the most powerful tool in judgement irrespective of any analysis or contemplation of the object, be it art, music or writings. In Jean-Baptiste Dubos' Critical Reflections on Poetry, Painting, and Music (1719), aesthetics is compared to 'taste' and he quips that one does not need to examine in detail every aspect of a ragoo to know whether it is good or bad:

\begin{abstract}
Do we ever reason, in order to know whether a ragoo be good or bad; and has it ever entered into anybody's head, after having settled the geometrical principles of taste, and defined the qualities of each ingredient that enters into the composition of those messes, to examine into the proportion observed in their mixture, in order to decide whether it be good or bad? No, this is never practised. We have a sense given to us by nature to distinguish whether the cook acted according to the rules of his art. People taste the ragoo, and tho' unacquainted with those rules, they are able to tell whether it be good or no. The same may be said in some respect of the productions of the mind, and of pictures made to please and move us (Dubos 1748, vol. II, 238-239).
\end{abstract}

Shelley (2017) indicates that basing an argument purely on the theory that 'beauty is in the eye of the beholder' implies that aesthetics is a malleable and inherently biased framework. In addition, as many beautiful objects have very complex natures or structures there may be a role for reason in their appreciation. In support of this thinking Hume contended "in many orders of beauty, particularly those of the fine arts, it is requisite to employ much reasoning, in order to feel the proper sentiment" (Hume $1751,173)$. In other words judgements of taste may be uncovered using empirical deduction. This idea that aesthetics is used to delineate between good and bad is still common in our society as it has been for centuries leading Eco to declare:

\begin{abstract}
'Beautiful' - together with 'graceful' and 'pretty', or 'sublime', 'marvelous', 'superb' and similar expressions - is an adjective that we often employ to indicate something that we like. In this sense, it seems that what is beautiful is the same as what is good, and in fact in various historical periods there was a close link between the Beautiful and the Good (Eco, 2004, 8).
\end{abstract}

Eco (2004) argues that the idea of beauty is a social construct that has morphed and changed throughout history as art and fashion evolve and reflect a society's changing values. If ideas of beauty and good are used as substitutes for each other then judgements about what is good will also be transient. My desire to create a film that has a high production value and therefore looks 'good' or 'beautiful' came in in second to my aim to visually portray the experience of drowning so that it reflected Catherines experience.

In relation to documentary, Corner (2005) contends that the idea of the aesthetic has been problematic as documentary is most often associated with television which has been considered to be an aesthetically impoverished medium and non-fiction filmmakers may not be interested in offering aesthetic experiences. He has developed a typology of documentary aesthetics which involves three key planes. The first is artifactual organization or consideration of documentary as a product of practice, the second is audience experience, while the third is that of theoretical and analytical inquiry (Rosenthal and Corner, 2005, 51). Corner regards the aesthetics of documentary under three broad headings - pictorial, aural, and narratological.

The pictorialism of documentary is itself inextricably linked to the long-standing debate involving the photographic image and literalism of representation. The pictorial qualities of film are constructed by the choices made in compositions, framings, angles, lighting, colourings, camera movements and editing. Aural influences in aesthetics although usually secondary to pictorial are nevertheless considerable and include choices in sound, such as music, voice and voice over. Narratological influences on aesthetics include decisions made about story formats with narrative satisfaction acknowledged by scholars as a property of nearly all formats (Rosenthal and Corner, 2005).

I believe that in relation to film, aesthetics are for the most part tacitly produced through experience, circumstance and budget. Nelson, (2013, 218) indicates that practice is the "key method of inquiry" and primary modes of knowing are located in the practice. Typically, film analysis happens long after the release of a film, often with the interpreter knowing very little about the practicalities of the production process itself. As the evaluation of the aesthetics for this film is by the filmmaker herself, then some of the analysis of aesthetics will be intrinsic to the production process of the film.

A different perspective on aesthetics has been offered by David Bordwell (1996) who links the concept of cinematic aesthetics both to cinematic technique and constructionism. He argues that the advancement of cinematic techniques, aesthetics and technical praxis has lead to an emergence of a "cross-cultural" or "universal" form of constructivism that allows for an understanding of cinematic language that seems to have emerged from cinema itself and is understood across cultural boundaries. As such, he maintains that to analyse different cinematic conventions in detail - for instance, the editing technique of shot-reverse-shot - one could look through the scope of constructivist filmmakers like Vsevolod Pudovkin who employs the machinery of shot-reverse-shot as a means of creating an omnipresent observer through the lens of the camera. Bordwell then contrasts this with the naturalist viewpoint that claims that because the shotreverse shot is such a deeply ingrained and widely used technique within cinema, it is "an arbitrary device, having no privileged affinities with natural perception" 
(Bordwell, 1996, 90). The edit itself breaks the long take as seen in Direct cinema as the construction of even observational scenes begin and end with an edit. However, the naturalists also acknowledge that as the perceptual skills of the viewers are enhanced so do the cinematic techniques which then makes such devices "arbitrary". The arguments between realists and constructivists are a version of the argument that has always been inherent in aesthetic film theory, that of realist vs non-realism.

The concept of aesthetics as linked to realism and to the role of art itself is not new to cinema. Indeed the idea of holding a mirror to nature and considering whether or not the reflected image fulfils an artist's purpose in society has been considered since Socrates and Plato, culminating in the notion that an artist should not just replicate the real world in his or her art but must somehow transcend the duplicate and instil style or their own aesthetic. Plato compared painting to a pale mirror of the truth (Kul-Want and Piero, 2012), suggesting that replication should not be the goal of art. This notion underpins the debates between the realist and anti-realist movements. Plato claimed in The Sophist (360BC) that there was a space linked to art that was separate from truth called the Simulacrum (Kul-Want and Piero, 2012). Plato likened the simulacrum to truthful representations by artists, that is, to arguments of mimetic reproduction and truth. In postmodern art theory the concept of the Simulacrum was advanced by Jean Baudrillard who claimed that it was a space where "the border between art and reality has utterly vanished as both have collapsed into the universal simulacrum... arrived at when the distinction between representation and reality - between signs and what they refer to in the real world - breaks down" (Appignanesi and Garratt, location 433). When this occurs a "hyper-reality" has been reached where images are no longer connected to reality or to meaning.

Plantinga (1997) built on Baudrillard's notions of simulacrum as well as the work of Allen Weiss (1990) and Colin MacCabe (1992) to present an argument that in this hyperreal state, images, films and videos are only versions of the simulacra and that within the post-modern environment the representation of reality is impossible:

For Baudrillard, then, this is not merely an inability to reach beyond appearances to reality, but a fundamental, irrevocable loss of access to reality. The human condition is to be mired in a world of mere simulation (Plantinga, 1997, 43)

In this hyper-reality the existence of a camera inherently changes the reality that it captures and often "has the potential to transform that reality in certain cases, as a part of the cultural discourses which carry on the process of transformation' (ibid, p45). If indeed we are located in the simulacrum where viewers and filmmakers are saturated with images that both document and have the ability to transform the reality they capture, then the contention between reality and images may be impossible to reconcile. Therefore, when exploring the links between authenticity and aesthetics in a postmodern context, the idea of absolute authenticity is negligible.

\section{The Sublime}

One aesthetic principle which resonates with this film is the idea of The Sublime. First put forward in the mid 1 st century AD by Greek rhetorician Longinus and then re-invigorated by Kant, it concerns the feeling of being overwhelmed, particularly in the face of nature and the grandness or power of the environment. Kant's depiction posited the Sublime as unrepresentable, as any encounter with the unknown or Other is inherently impossible to replicate. The concept of representing the unknown became increasingly important in modern art with the move away from realism and the positioning of art as being able to portray more than a reflection of nature, redundant in art with the invention of photography. With the notion that art could go further than simple reproduction, Russian artist Kasimir Malevich (1878-1935) painted a white square on a white canvas and claimed in his 1919 Manifesto of Suprematism that he had achieved in painting The Sublime (Kul-Want and Piero, 2012).

Kant linked his concept of the Sublime, which fell into his concepts of Universal Reason, to quasireligious sentiment and linked it to his later theories of "Disinterment" and "Reason". This idea was further developed by the Christian philosopher Hegel who purported that all experiences known or unknown were part of God's plan (Kul-Want and Piero, 2012). This link between the Sublime and moral precepts has also been used by cinema theorist Cynthia A Freeland who claims "When we find a film sublime, we both evaluate it as an excellent, superlative great artwork, and are also elevated by reflection on the moral issues it raises and its perspective on those issues" (Freeland, in Plantinga and Smith, 1999, 83).

The idea of representing a person's interaction with the forces of nature is paramount to this project as it conveys an individual's experience of drowning and being all-consumed by the forces of nature. Tracking Catherine's narrative to the Instinctive Drowning Response which is a set of auto-physiological responses that occur once someone begins to drown removes the idea of a drowning event as unknowable or unrepresentable. Indeed it is visualising this experience alongside images of this auto-physical response that strengthens the authentic emplotment of Catherine's narrative which engages with notions of the Sublime as it represents what is inherently difficult to represent. Catherine Redmond's feelings of isolation were evident when she said "Life was going on all around me...I was just a blip in the ocean", this reaction to feeling so small and helpless within the vastness of the ocean, can indeed be seen as an encounter with the Sublime.

When Catherine watched as her story was told on film in the cinema it really struck her that she had been drowning. As an audience member the reflection of her own story told back to her with images of an endless ocean and vast landscapes brought about the 
feeling of The Sublime. Freeland (1999, 66, quoted in Pezzotta, 2013, 165) posits that "Kant and Burke emphasized that so long as we are safe, the ineffable, great element before us in the awesome object evokes a certain intellectual pleasure of astonishment or elevation." Sitting in the safety of the cinema Catherine was overwhelmed with the power, danger and feelings of the Sublime evoked by the culmination of her own testimony and its visual emplotment. She was able to feel The Sublime as an audience member and enjoy the "intellectual pleasure" and "astonishment" that was allowed by her new role as a self-reflexive spectator (Babbage, 2015, 48-51).

\section{Authenticity}

Concepts of authenticity have been linked to documentary production as well as all art forms since their beginnings. There have been many interpretations of what constitutes an authentic documentary but overwhelmingly, theorists like Nichols, Eisenstein, Vertov and Plantinga all acknowledge the basic concept that it is a nonfiction story told faithfully by the filmmaker. Nichols (2017) outlined his three rules of the documentary film as being based "in reality...about real people...[and] tell stories about what really happened" (Nichols, 2017, 23). This is a great starting point for what it means to be an authentic documentarian as it gives the filmmaker freedom in terms of style, form and creative production. Nichols (1991), while recognising the constructed nature of both fiction and documentary film forms, indicates that the two are distinguished not by their common filmic techniques but by their conflicting artistic philosophies "documentaries always were forms of representation, never clear windows into reality" (Nichols, 2005, 18).

Nichols further breaks down subsections of authenticity in documentary in terms of tools for representation but clarifies again that an image itself may seem persuasive but that does not mean it is authentic. Images can be manipulated in the filmic process, in postproduction or merely through a misleading argument. Therefore, the authenticity of the "internal logic and external verification of what a documentary claims to be true must be rigorously assessed " (Nichols, 2017, p26). Ultimately Nichols positions himself in a stronger constructionist stance when he acknowledges that in the postmodern documentary tradition reality is no longer assumed and therefore the role of the filmmaker is to create an authentic world but one which is solely a construction of how they view the filmic representations that they develop:

A documentary is more than indexical images, more than the sum of its shots: it is also a particular way of seeing the world, making proposals about it, or offering perspectives on it. It is, in this sense a way of interpreting the world. It will use evidence to do so. Unlike the individual shots or sounds, an interpretation does not have an indexical relation to reality; it is unique to the filmmaker, not reality (Nichols, 2017, 24).
Nichols argues that with the evolution of documentary, practice no longer confines documentary to realist notions of authentic representation. Renov's (2012) observed that all non-fiction films necessarily contain "fictive" elements as objective representation requires creative intervention. This practice of recreating scenes or mixing non-fiction narratives with fiction visuals has been present since the beginning of documentary film. Indeed many of the pioneering directors of documentary used this technique to such a degree that under a contemporary critical lens their films may not even be considered as documentaries (McDonald and Cousins, 2011, 95). Pioneers like Grierson used actors, sets and scripts while Flaherty used recreations in Man of Aran (1934) and Nanook of the North (1922) both of which were a collaboration with the documentary subjects where they recreated hunting techniques of the past and portrayed a life more suited to their grandparents than to the society being filmed. Although Grierson and Flaherty both used recreations, their filmmaking approach was rooted in the tradition of realism. This was "not an attempt to authentically capture reality but an attempt to use art to mimic it so effectively that the viewer would be pulled in without thinking about it" (Aufderheide, 2007, 47). Renov (2012) concurs, stating that documentary filmmakers need to be cognizant of the source of nonfiction's deep-seated appeal which he sees emanating from its ability to harness viewer's imagination. It is important to understand the history of realism and the fashion of form and style of documentary photography to understand the role of recreations in today's cinema.

De Heusch (1962) defines authenticity in documentary by relating it to the intentions of the director. For him, documentary films can be staged and use actors or reenactments which can all be considered true as long as it reflects what the director understands to be true:

The authenticity of this sort of "documentary" ultimately depends entirely on the honesty of the director, who, through his work, asserts that "This is what I saw." In fact he has not seen exactly this or that aspect of what he shows, he has not always seen these things in the way he shows them, since that way is a language which he invents in cooperation with actors roles are authentic. The documentary is a work of art imbued with rationality and truth (De Heusch in Tobing Rony, 1998, 116).

De Heusch mirrors the sentiments of Nichols and Renov locating the authenticity of a non-fiction film in the aspirations and constructions of the filmmaker. The understanding of authenticity has evolved throughout the various documentary trends that have occurred. Modern documentaries often incorporate mixed media, animations, graphics and re-enactments and still position themselves under the umbrella of "authenticity". In the production of Far Away Land the ideas of authenticity were framed within a willingness to translate Catherine Redmonds story to film form as I understood it. 


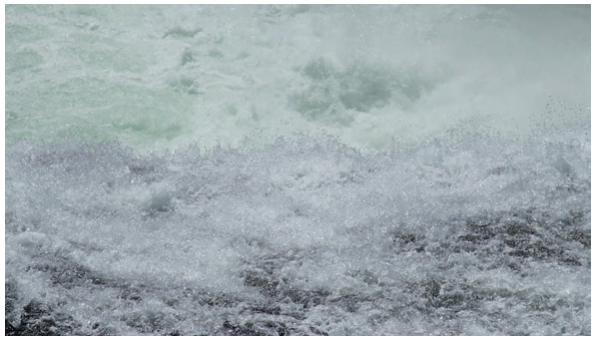

Image 1 - Spray (O'Toole, 2017) [Original Photograph]

\section{Catherine Redmond's Story in Far Away Land}

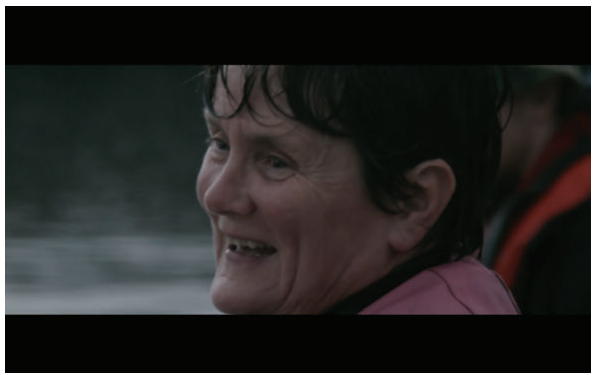

Image 2 - Far Away Land (O'Toole, 2017) [Video Still]

Catherine Redmond is an avid diver and has spent many years negotiating problems and troubling situations as they arise under the sea. When I approached her about being part of this study she agreed without hesitation, but said that although she had had several frightening experiences in water she wished to speak only about the one time she thought that she was drowning and was about to die. This was my first experience of relinquishing control to a participant collaborator. At the time I was curious about the other incidents that Catherine had been involved in and I felt that I would like to hear more so that I could make the choice about which story to listen to. However, mindful of the need for legitimate collaboration (Barbash and Taylor, 1997, MacDougall, 1998), I constrained my instinct to control the storytelling process and listened to the only story that Catherine wanted to relate.

Catherine started her interview with stories of growing up in an old lifeguard house on the Irish northwestern seaboard and learning to swim by copying the dog and jumping off rocks with her siblings. She went on to relate her experience of trying, unsuccessfully, to swim lengths in an Olympic pool. In narrating this smaller story Catherine indicated that she had realised that she wasn't a strong swimmer even before she got into serious difficulties in North America swimming off the coast of Maine. This narrative device of foreshadowing is used to reduce the surprise in a subsequent story (Pettijohn and Radvansky, 2016).

The story Catherine related is a simple story about going out for a swim by herself at a beach she was visiting for the first time. She swam out to sea, enjoying herself and delighting in the scenery but when she headed back to shore she realised that the tide was very strong. She had been swept down the beach and was unable to return to shore. Catherine recalled that she tried different approaches to get back: swimming on her back, approaching the shore from different angles and using her feet to scramble up the stones underneath her, but none of these techniques proved fruitful. Drowning incidents are commonly undramatic and quiet. There is no waving of arms or calling for help as this exertion would inhibit breathing and it is an autophysiological response not to do so (Golden and Tipton, 2002). This was reflected in Catherine's interview when she exclaimed that she didn't know why but she didn't call for help even though she could see a lifeguard.

The next stage in Catherine's story reflects feelings of apathy, another common theme in drowning experiences. She articulates the fact that she just gave up and knew that she wasn't going to get back to shore so she turned around and began floating on her back. This feeling is common in drowning scenarios as often people are overwhelmed with a sense of apathy and, although they might know the steps they could take to help save themselves, they just choose not to do so (Golden and Tipton, 2002). Catherine also stressed at this point that she could look down the beach and see other swimmers enjoying themselves. Knowing that she was going to die and they were going to live on, she was aware of feeling that it was so unfair that they were going to continue to live without her.

When Catherine had given up and was floating on her back she saw her companion come around a corner high up on a cliff. She knew the two could see each other but that there was nothing either of them could do to save her. She acknowledges the pain that this incident also had on her companion who thought she was witnessing her friend being swept out to sea. This part of the interview is very important, as it acknowledges the dilemma of witnesses and demonstrates that the impact of these experiences is not always confined to the people in the sea. Unfortunately, this section was too tangential to feature in the final film. A chance wave threw Catherine onto the beach and ended her ordeal in the sea. Without this luck, Catherine believes she would not have survived and although she was aware she had not inhaled or swallowed water she believed that she was drowning. As Catherine has a PhD in physiology her interpretation of her physical condition is likely to be accurate.

In the course of this interview, Catherine indicated how this event had changed her life. Although her story took place somewhere else when she was about thirty years younger, she admits that, even now, she would never attempt to save a person who was drowning or in difficulty knowing that she would not have the strength and she now understands that a drowning person is too erratic and unreliable. Catherine went on to say that she was not certain that she could even save her children if they were in trouble. This is an illustration of a changing construction of the self as Catherine's sense of self-efficacy has been altered irrevocably (Hyden, 2010). 
Catherine constructs herself as disliking being in the open water but delighting in being in the otherworldliness under the ocean, where she knows she can aid someone who is in difficulty by simply using her spare regulator. I wanted to express this dichotomy in the film and present both Catherine's fear of the open water and also her love for the depths. Far Away Land introduces Catherine's character as someone who loves the sea; we watch her prepare to go diving, seeing her relaxed and chatting with her fellow dive buddies. We follow her into the water and are given a glimpse into the captivating and exotic nature of the deep sea. This section sets up Catherine's world and also demonstrates what an adventurous and active woman she is.

When Catherine resurfaces from her dive we make the transition into the past. Her story occurred thirty years before so the rest of the documentary is a recreated scene using an actress (my sister, who is also called Catherine) to visualise her story. The shots in the film become more abstract as the film develops, adding a layer of intrigue and confusion to the viewer. This reflects Catherine Redmond's unease but does not fall into melodrama or heightened dramatics.

The pacing of the narrative was very important; it is a story about how non-dramatic a drowning situation can be. Contrary to a common belief that drowning involves screaming, shouting, waving and thrashing about, Catherine's story is one of a calm yet very difficult situation. To create a variety of shots for the sequences needed to tell this story, many filming techniques were utilized. These included photography to capture the situation under the water, drone photography to show the expansive landscape, still landscape photography to set a calm mood and tone, and partially submerged camerawork to create a feeling of unease where viewers can see clearly above water while everything beneath the water line is obscured.

\section{Film Visuals}

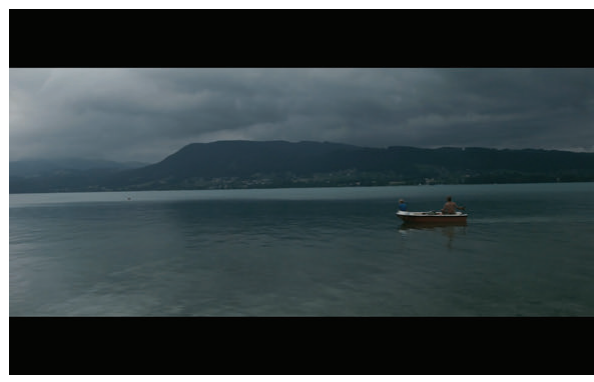

Image 3 - Far Away Land (O'Toole, 2017) [Video Still]

\section{Feeling of Isolation - Camera Work}

Originally when filming this documentary, I wanted to create an isolated and claustrophobic feel that would reflect the feelings of loneliness and detachment that drowning victims frequently describe (Golden and Tipton, 2002, 239). I shot this film on a Blackmagic Pocket Cinema Camera as this small lightweight camera is both easy to operate by one person and it captures ProRes 422, producing high-quality images for all shots on the ground. In the water, I used a GoPro 4 Silver, a waterproof camera that produces good quality video. The GoPro naturally has a curve in its angle of view which creates a distortion within the frame and I believed this would work successfully to heighten the visual tension of such a terrifying event. Initially, the plan for this sequence was to maintain a highly subjective frame, one that fully enveloped my sister Catherine while ignoring the geography around her, and refrained from cutting to wider shots as this would disrupt the intended claustrophobia. This type of subjective composition has worked well in films such as László Nemes Son of Saul (2015) and Gus Van Sant's Elephant (2003) to create an experience for the viewer that is firmly anchored by a character's perspective, removing the audience's objective viewpoint. This creates a sense of unease and ultimately connects the viewer more closely with the subject of the film.

Unfortunately, this plan did not work for my film; in the edit, these sequences were repetitive and boring, I was unable to continue the long and invested shots that are needed to create the desired link between audience and character. My shots were continually disrupted by waves, my own buoyancy and by the need to match my sister's swimming technique. The beauty of the extended shot was not present in my camerawork. Instead, it was a collection of long rushes that badly needed editing.

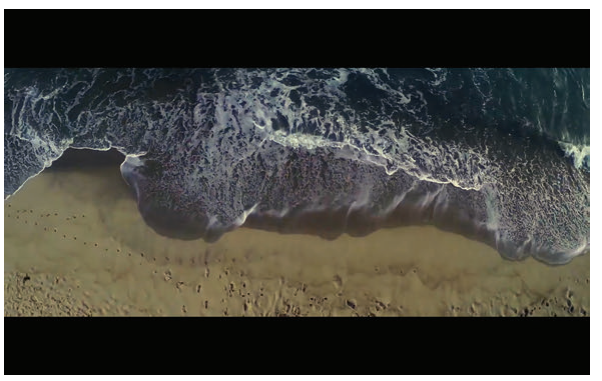

Image 4 - Far Away Land (O'Toole, 2017) [Video Still]

To fix this narrative problem I needed to juxtapose the intimate fight for survival with the expansive landscape. Placing these images side by side emphasised the isolation felt in being one person alone fighting against such a powerful force. This was achieved by adding drone footage which was filmed both in Ireland and Nantucket. The Nantucket segment was shot by Damon Cooper and Simon Keenan. The sweeping aerial photography provided the scale that the story needed, so when Catherine Redmond says "just a blip in the ocean" we can really visualise the immensity of the sea around her and feel the true impact of her situation. The drone footage also adds controlled movement to the film, providing relief to the handheld GoPro footage, which was somewhat shaky and unpolished. Juxtaposing images to create atmosphere and engage the viewer is not a new 
technique and its use can be traced back to Dziga Vertov and the Russian constructivists which will be explored in the next section.

\section{Feelings of Isolation, the interval of movements and the aesthetic teachings of Dziga Vertov}

Vertov was very engaged with the issues involved with authenticity and aesthetics, he "strove to achieve a balance of authentic representation and "aesthetic" reconstruction of the external world" (Petric, 1987, 8). Vertov wanted to turn away from traditional aesthetics which he deemed redundant and create a new aesthetic out of this revolutionary new form reflecting the new Soviet state. His balance between authenticity and aesthetics was the transition from production to postproduction. For Vertov as long as the film had been captured "authentically" it could then be manipulated during the editing process through montage to create a higher meaning and often abstract aesthetic.

Vertov believed fervently in the importance of showing "life-as-it-is." In his most famous work Man With A Movie Camera (1929) he embodies the telling of small narratives, reflexively telling the story of himself filming the documentary and capturing small narratives of every day events. The emplotment or visualisation was spectacular and he employed all of his technical skill and camera trickery. Vertov sought to create a "sweeping panorama of a transformed nation, where unconsciously the daily lives of ordinary people had become part of a magnificent modernist poem" (Aufderheide, 2007, 62). His aim was to show small narratives in order to create a grand portrait of a new and powerful country built on the power of the people. The plot was an insight into the life of a filmmaker and the ordinary Russian people, while the emplotment was a kaleidoscope of abstract images that still complied with Vertov's idea of truth.

The Russian poet and critic Pytor Pertsov described the style of Vertov's filmmaking as an attempt to capture authentic visuals and then construct them in a manner that the filmmaker desired. This process of "kinematografiya" or creating "tectonics" that allow the filmmakers/engineers to structure the film that best suits their understanding is an important part of Constructivist cinema technique, and is one which I have used in this project. Below Petric outlines how Pertsov understood Vertov's work to be a type of bricolage:

...Vertov's method demonstrates his understanding of the two crucial aspects of Vertov's work: first, the evident ontological authenticity of each separate shot ("the non-aesthetic impact of the shot") and second, the montage organization of the footage ("building a structure"), by which the filmmaker reconstitutes the spatiotemporal aspect of reality and conveys his message ("makes his point") while "holding the attention of the audience" (Petric, 1987, 20).

For the constructivists there was an important difference between the film footage and the film after it has been edited. The combination of the choice of edits to construct the story, the juxtaposition of shots, the ideological reasoning and their construct of truth they called 'Montage'. Montage was extremely important to the constructivists and has influenced my choices in the production of this film. Pertsov points out that for Vertov the power of montage was in its ability to articulate a point while entertaining the audience. However, the concept of montage goes far deeper for the constructivists especially Sergei Eisenstein who believed that new meanings can be created by the juxtaposition of two shots (Eisenstein, 1986). One of the founding fathers of Russian cinema, Eisenstein rallied against the idea of cinema aesthetics, instead pushing his long held belief in montage. Eisenstein indicates that his idea of montage incorporates not just the cutting and splicing of film into sequences but as a philosophy outlining the basic aim and function of montage as being "that role set itself by every work of art, the need for connected and sequential exposition of the theme, the material, the plot, the action, the movement within the film sequence and within the film drama as a whole" (Eisenstein, $1958 / 1986, p 13)$. This seems to fit the idea of mise-enscene and aesthetics too but Eisenstein was staunchly anti- Kantian in his rejection of the purposelessness of art. He believed higher meanings arise from elements of a film's editing and production (Smith, 2001, 464 in Gaut and Mclver Lopes).

A big difference between Vertov and Eisenstein was Einstein's belief in perekraivanie: the action of actively and consciously remaking reality (Petric, $1987,49)$. The idea of perekraivanie would become popular in documentary production from the 1960s onwards when recreations became a common way of visualising testimony and it strongly influenced this project. The majority of this film is a reenactment based on Catherine's testimony. This goes against Vertov's concept of capturing "life-unawares" however, there are still many lessons learnt from Vertov's rules of filmmaking that were influential in this documentary. For Vertov the impact of each shot was understood by its "image composition, juxtaposition of shots, and cinematic integration of all components, including the narrative" (Petric, 1987, vii) after judging the shots by this criteria one could then build these shots into a structure using filmic techniques. One such theory was his "Theory of Intervals" which was implemented to solve some problems in the original edit.

The influence of Vertov's "Theory of Intervals" or "Intervals of Movement" techniques can be seen in Far Away Land in the juxtaposition of drone shots and close-ups. Vertov believed two different camera movements one after the other causes a conflict in the mind of the viewer and by intercutting two sequences "both sequences retain a phenomenological semblance of photographed objects and events. Their cinematic abstractions, however, begin at the point where the intervals approach the awareness threshold, creating an oneiric vision that makes an impossible situation probable" (Petric, 1987, p148). The impact of my use of a drone shot in this instance is similar to the impact that Vertov achieved in tracking shots which he believed severed the human eye from the 
mechanical eye thus creating a battle in the minds of the viewers. The "kinesthetic power of the "Film-Eye" method" (Ibid) stems from this breach in equilibrium that occurs when placing two shots with contrasting momentum beside each other. It was only after the inclusion of a second sequence into Far Away Land that the emotive qualities of Catherine's story of finding herself in a drowning situation were manifest. It is the use of Vertov's interval of movements technique that allows the viewer to experience Catherine's feelings of isolation in a large ocean.

\section{Contrasting Landscapes}

The use of drone shots to create a feeling of apathy, tension and the feeling of an overwhelming environment is one that Stella Hocknull (2012) points to in her analysis of The Queen (2006) which utilises this juxtaposition of subjective images and sweeping forest landscapes:

Significance is achieved not by what is visible to the eye, but by what lies ahead. The horizontal floor of the forest forms an axis to the upright trees, and the filtering light suggests an abyss and a promise of a presence beyond. This sensation is reinforced as the film cuts to an aerial view of the landscape. The Queen is no longer visible, and the spectator is permitted to enjoy the landscape from a perspective not available through her point of view. This shot ensures that the landscape appears isolated and hostile; it adopts antagonistic characteristics, mobilising a sense of loneliness (Hocknull, 2012, 170).

Contrasting images of characters to vast landscapes creates a visual narrative of smallness and isolation. It allows viewers to simultaneously place themselves in the event whilst also giving them God's eye view of the environment. This omniscient view is privileged to the viewers alone and emphasises the problematic event occurring for our character in the case of Far Away Land - that of Catherine's drowning experience. This feeling of isolation, powerlessness and apathy is regularly described in the testimony of drowning (Golden and Tipton, 2002) and the ability to replicate this in the viewer is powerful. Hocknull suggests that this aesthetic technique invites feelings of the Sublime "'suddenness' whereby a forceful transition takes place for the spectator" (in Hocknull (2012) Burke 2008, 76) this concept mirrors that of Vertov's “Theory of Intervals". Both require the viewer to be challenged by the editing of conflicting movements and scale to create an emotional impact through montage.

Hocknull suggests that the environment can become an antagonistic force within the narrative. Its visualisation not only creates a hostile backdrop for our story but the omniscient view "precludes access to the image. The spectator is rendered exposed and vulnerable as onlooker, unable to attain a level point of entry into the composition" (Hocknull, 2012, 172). This can also be seen as mirroring the experience of those who see a drowning event from the shore as drowning often presents as quiet and unspectacular so the onlooker is removed from the event. Therefore, creating this space of removal and contrasting it to intimate close ups of Catherine that are mapped onto the physiological movements of drowning was important to the authentic emplotment of Catherine's story.

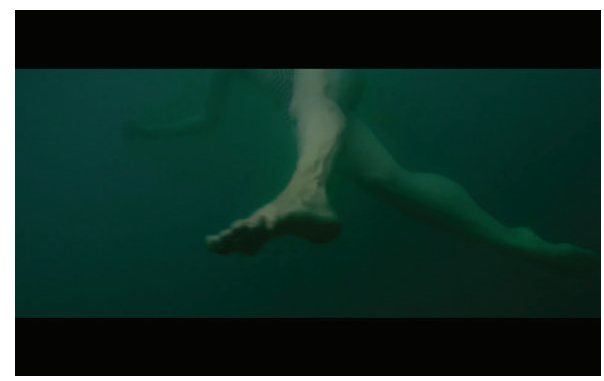

Image 5 - Far Away Land (O'Toole, 2017) [Video Still]

\section{Film Screening}

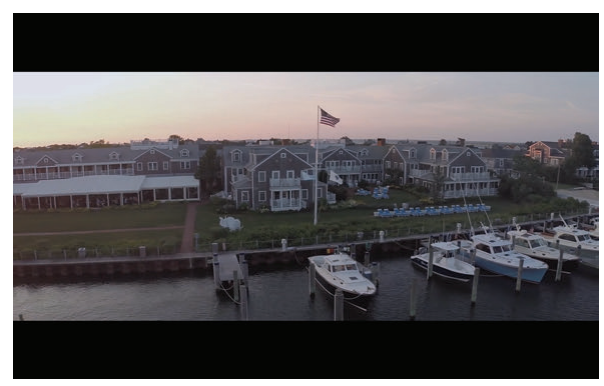

Image 6 - Far Away Land (O'Toole, 2017) [Video Still]

The film's premiere was part of the Irish Film Institute's Documentary Festival 2017, where it was chosen to be screened along with six other Irish and international short films. This was the first time Catherine Redmond had viewed the film. Although she had been invited to see the documentary at several stages of its production, Catherine said she wanted to wait for the "big screen" and came with her sister to the showing. After the screening, Catherine said she was very impressed by the film and highlighted the words she spoke, "And I was just a blip in the ocean, and life was going on without me, and you don't like to think about that". Her interview had taken place over twelve months prior to the screening and she had forgotten what she had said but she kept reiterating that that was exactly how she felt, and she found re-hearing her own dialogue very moving.

Catherine said she was delighted to be part of a piece of art, describing how wonderful it was to be a participant in something creative and how happy she was with the overall film. She indicated that she was impressed by the translation of her interview into film form. I asked her to write a short reflection in her own words: 
I was a little nervous before going in but mostly curious to see how you made a film out of the interview. I couldn't imagine how this could be done and hadn't given much thought to what I had said during the interview or the emotions it had provoked. After the first film the screen went dark and then there was a voice talking. It took me a minute to realise it was me and that the film had started. My strong Northern accent was a shock to me - I always laugh at my sisters who are still up in Donegal at their accent! Didn't catch at all what I was saying - until my sister Thérèse started to grip my arm and say I didn't know you went through that! Then I started paying attention to the words and not just the scenes.

The first "gulp" moment for me was seeing Nantucket Island again - couldn't believe that it was up there, the place where this had happened. The images are so close to what I remember, felt as if we were stepping close to something threatening and very personal. The next stand out emotional part for me was when I said something about life going on up the beach while I was drowning just further down you did a quick pan to this "life" - surfers, swimmers, sounds of a beach - and that whole moment when I felt that years ago flooded back. I think it was the sounds that were the most evocative - stillness where I was but sounds drifting down. Made me feel very inconsequential then and again when watching the film. That truth - that we are just a dot on the great scheme of things - has always stayed with me and sometimes helps when I take knocks too seriously or sometimes hinders when I don't treat things seriously enough.

I lost a bit of the film after that moment so I felt that suddenly it was over and I hadn't paid enough attention.

(Redmond, email correspondence to author, 2017)

Catherine's reaction both in the water, in her telling of her story and, again, when she watched the film back to the part when she realised life would go on without her could be classified as an epiphany: an important moment of clarity which disrupts a person's life and creates a new perception of how they see the world (Denzin, 2001, Bruner, 2002, Paulus et al., 2007). At this point Catherine realised her own mortality and she saw herself as just "a blip". These epiphanies both big and small are important in narrative theory, providing insights and acting as turning points in the narrative (Riessman, 2008).

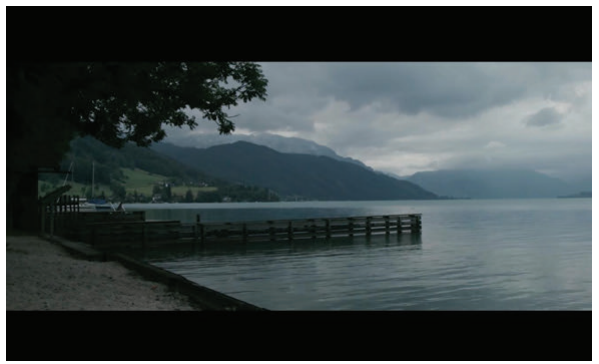

Image 7 - Far Away Land (O'Toole, 2017) [Video Still]

\section{Conclusion}

Within this paper I have sought to articulate the conceptual, aesthetic and creative forces that underscored a documentary about one woman's recollections of an experience in the waters off Nantucket when she thought she would die. This film is part of a larger PhD project which is concerned with aesthetically and authentically documenting stories of drowning. There is a tension in all documentary film production between the competing forces of aesthetics and authenticity which were manifest here as a struggle between the desire to make a visually beautiful film that was also true to the narrator's story and the physiological process of drowning. Using the concept of plot vs emplotment from narrative theory which delineates between the plot, which is the story being told, and emplotment which is how it is visualised, I have used the word 'plot' to delineate Catherine Redmond's story and 'emplotment' to describe the visual storytelling that accompanies her narration. Some of the theoretical influences from several filmmakers in the production of this documentary were discussed as a way of locating this documentary in a lineage of practice. In addition this paper provides an insight into the thinking behind the practical and aesthetic decisions involved in the making of this documentary. Far Away Land authentically told Catherine's story as I understood it, and using recreations and present-day footage as an aesthetic approach provided a natural fit in capturing her story. In addition to its screening at the Irish Film Institute's Documentary Festival, Far Away Land was also selected to be shown in November 2017 in The Panorama of European Film Festival in Cairo, Egypt, and the 2018 Belfast Film Festival.

\section{Bibliography}

Appignanisi, Richard. Introducing postmodernism: a graphic guide. Icon Books, 2004.

Aufderheide, Patricia. Documentary film: A very short introduction. Oxford University Press, 2007.

Babbage, Frances. "Active audiences: spectatorship as research practice." Studies in Theatre and Performance 36 , no. 1 (2016): 48-51.

Barbash, Ilisa, and Lucien Taylor. Cross-cultural filmmaking: A handbook for making documentary and ethnographic films and videos. Univ of California Press, 1997.

Bordwell, David, and Janet Staiger. "Kristin Thompson." Film Art: An Introduction 8 (1985).

Bordwell, David. "Contemporary film studies and the vicissitudes of grand theory." Post-theory: Reconstructing film studies (1996): 3-36.

Bruner, Jerome. "Making stories: Law, literature." Life 23 (2002).

Denzin, Norman K. Interpretive interactionism. Vol. 16. Sage, 2001.

Dubos, Jean Baptiste. Critical reflections on poetry and painting. Nourse, 1748.

Eco, Umberto. "On Beauty." (2004).

Eisenstein, S. "The film sense (J. Leyda, Ed. \& Trans.)." (1986). 
Gaut, Berys, and Dominic Lopes, eds. The Routledge companion to aesthetics. Routledge, 2013.

Good, Byron J. Medicine, rationality and experience: an anthropological perspective. Cambridge University Press, 1993.

Golden, Frank, and Michael Tipton. Essentials of sea survival. Human Kinetics, 2002.

Grierson, J. Grierson on Documentary. London: Collins, 1946.

Heusch, Luc de. "The cinema and Social Science: A Survey of Ethnographic and Sociological Films." Reports and Papers in the Social Sciences (1962).

Hill, John, Pamela Church Gibson, Richard Dyer, E. Ann Kaplan, and Paul Willemen, eds. The Oxford guide to film studies. Oxford: Oxford University Press, 1998.

Hockenhull, Stella. "Remystifying Film: Aesthetics, Emotion and The Queen." Film-Philosophy 16, no. 1 (2012): 165-182.

Hume, David. An enquiry concerning the principles of morals: a critical edition. Vol. 4. Oxford University Press, 2006.

Hyvéirinen, Matti, Lars-Christer Hydén, and Marja Saarenheimo. "Beyond narrative coherence." Beyond narrative coherence 11 (2010): 1.

Kul-Want, Christopher. Introducing Aesthetics: A Graphic Guide. Icon Books Ltd, 2014.

Macdonald, Kevin, and Mark Cousins. Imagining reality. Faber \& Faber, 2011.

MacDougall, David. Transcultural cinema. Princeton University Press, 1998.

Nelson, Robin. Practice as research in the arts: Principles, protocols, pedagogies, resistances. Springer, 2013.

Nichols, Bill. Representing reality: Issues and concepts in documentary. Vol. 681. Indiana University Press, 1991.

Nichols, Bill. "The voice of documentary." New challenges for documentary 19 (2005).

Nichols, Bill. Introduction to documentary. Indiana University Press, 2017.

Paulus, Trena M., Marianne Woodside, and Mary Ziegler. "“Determined women at work”: Group construction of narrative meaning." Narrative Inquiry 17, no. 2 (2007): 299-328.

Petrić, Vlada. Constructivism in Film-A Cinematic Analysis: The Man with the Movie Camera. Cambridge University Press, 1987.

Pettijohn, Kyle A., and Gabriel A. Radvansky. "Narrative event boundaries, reading times, and expectation." Memory \& Cognition 44, no. 7 (2016): 1064-1075.

Pezzotta, Elisa. Stanley Kubrick: Adapting the Sublime. University Press of Mississippi, 2013.

Plantinga, Carl R. Rhetoric and representation in nonfiction film. Cambridge University Press, 1997.

Plantinga, Carl, and Greg M. Smith, eds. Passionate views: Film, cognition, and emotion. BRILL, 1999.

Redfern, Nick. "Film as Text: Radical Constructivism and the Problem of Narrative in Cinema." Amsterdam International Electronic Journal for Cultural Narratology 2 (2005).

Riessman, Catherine Kohler. Narrative methods for the human sciences. Sage, 2008.

Renov, Michael. Theorizing documentary. Routledge, 2012.

Rony, Fatimah Tobing. "The Lost Emperor." Bertolucci's The Last Emperor: Multiple Takes (1998): 137.

Rosenthal, Alan, and John Corner, eds. New challenges for documentary. Manchester University Press, 2005.

Shelley, James. "The concept of the aesthetic." (2017)

\section{Filmography}

Elephant (2003) Directed by Gus Van Sant [Film], USA: HBO Films.

Man of Aran (1934) Directed by Robery J Flaherty

[Film], Ireland: Gainsborough Pictures.

Man With A Movie Camera (1929) Directed by Dziga

Vertov [Film], Russia: Vseukrainske Foto Kino Upravlinnia

(VUFKU).

Nanook of the North (1922) Directed by Robery J

Flaherty [Film], Canada: Pathé Exchange.

The Magnificent Ambersons (1942) Directed by Orson

Welles and Fred Fleck (uncredited) [Film], USA, Mercury

Productions.

Son of Saul (2015) Directed by László Nemes [Film]

Hungary: Laokoon Filmgroup.

The Queen (2006) Directed by Stephen Frears [Film]

UK: Pathé Pictures Intervational.

Greed (1924) Directed by Eric Von Stroheim [Film] USA:

Metro-Goldwyn Pictures Corporation 